\title{
Editörlüğe Övgü
}

\section{Praise of Editor}

\author{
Yalçın Yalçınkaya*
}

$\ddot{O}_{\boldsymbol{z}}$

Bu çallşmada; editörlük konusu incelenmekte olup, bilimsel yaymm kapsamminda editörün işlevi ve önemi üzerinde durulmaktadır. Bilimsel eserin; matematiksel nesnelliği ve bilimsel geçerliliği için editör önem taşımaktadır. Editör, tek boyutlu bilginin üç boyutlu hale gelmesinde etkin ve etkilidir. Yeniliğin bilgi ile geleceğine inanmakta, bilginin kalıcılı̆̆ için çalışmaktadır.

Anahtar Sözcükler: Editör; bilgi; bilimsel yayın; yaytm; lektör.

\begin{abstract}
This study investigates the issue of editorship and emphasizes the function and significance of editor within the scope of scientific publication. The editor is important on the mathematical objectivity and scientific validity of a scientific work and it is effective and influential in the transformation of one-dimensional information to three-dimensional information. An editor believes in the future with innovation and works for the permanence of information.
\end{abstract}

Keywords: Editor; information; scientific publication; publication; lector.

Editör, sözcük anlamı olarak "yazıları yeniden düzenleyerek yayıma hazırlayan kimse" (Türk Dil Kurumu, 2017a) olarak betimlenmektedir. Bir alanın, kendine özgü niteliğini ve temel ilkesini en açık biçimde ortaya koyan bu yaklaşım aynı zamanda bir nesnenin, en yalın biçimde tasvir edilmesi sürecini de içermektedir.

Dilin, düşün ve düşüncenin; söz ve/veya yazı dizinimselliğiyle canlılık kazanması, varlıksal niteliğe dönüşmesi yayın/yazın oluşumunu sağlamaktadır. Yayın/yazım ise kendi kaynağından dışarıya ancak yayım sayesinde evirilebilmektedir. İşte bu bağlamda yazar; sözün, sesin, yazının, eserin sorumlusu olmaktadır. Kalem sahibi olmanın kudretine erişmiş en yetkin kişi kendisidir ve üstelik yapıt veren kimse olarak önemlidir. Bir anlamda, büyük bir emeğin sonucunda ortaya konulan eser; gerek biçim ve gerekse biçem bakımından bütünlük taşıyan bir ürün konumundadır. Bu bağlamda duygusal, duyusal ve bilgisel tepkime sonucunda doğan özdek sözleşmesi, yazarındır.

Bilgisel ve bilimsel eserin, yayıma hazırlanması yetkisi ise editöre aittir. Duygu birikiminde ve bilgi kültüründe üretilen özgün yeniliklerin bir alanda tohum vermesi, yetiştirilmesi ve büyütülmesinde sorumlu kılınan kiş̧i kendisidir. Her yazarın editör olmamasına karşın editör; hem yazar/yazıcı hem de yazar/yaratıcı olabilmektedir. Yazınsal uğraşın yaşam bulmasında, yazara maddi ve manevi yardım sağlayan, editör olmaktadır. Çalışmanın, eserin yıkılmaması, güçlü kılınması için editör, en büyük dayanaktır. Elbette, bu uğraşın; doğrultusu,

\footnotetext{
${ }^{*}$ Kütüphaneci, Marmara Üniversitesi S.B.E. İletişim Bilimleri ABD Bilişim Bilim Dalı Yüksek Lisans, e-posta: yalcin.yalcinkaya@hotmail.com

Post Graduate Librarian. Marmara University Institute of Social Sciences, Department of Communication Sciences
}

Geliş Tarihi - Received: 14.01.2017

Kabul Tarihi -Accepted: 11.02.2017 
yönü, süresi sonsuz değildir. Matematiksel nesnelik ve bilimsel geçerlilik doğrultuyu ve yolu etkilemektedir. Nitelik ve nesnellik aralanan ve aranılan canlı yaşamın gözesidir. Söz dizimi ve anlatım aracı olarak dil, yazar - editör ya da editör - yazar iletişimini, ilişkisini ve işbirliğini oluşturmaktadır. Böylesi bir anlatım aracı; sözcük ve işaret kullanarak anlaşmanın olduğu kadar çatışmanın da anahtarı olabilmektedir ancak dilin ve bilimin kendi değer yargılarına göre şekillenmiş ortak kuralları; aidiyetin sağlanması ve kimliğin oluşturulmasında en büyük sistemdir. Söz/bilgi hazinesi kullanıldığı anlarda büyüdüğü ve taşındığ1 alanlarda çoğaldığı için değerini hep korumaktadır. Bir anlamda editör; bu hazinenin geliştiricisi, bilginin/düşüncenin/değerin nasıl daha iyi sunulabileceğine çalışan gül yetiştiricisidir

Editör, önündeki işin, oluşun sonucunda bağımsız ve bağlantısız olarak süre harcamakta, zamanını tüketmektedir. Üzerinde çalıştığı yazıda/eserde belirtilen geçmiş, şimdiki ve gelecek zamandaki fikirlerle geniş zamanlarda gezinmektedir. Editörün, yeryüzü atlası her defasında, yıldız burcundakilerin enerjisiyle yenilenmektedir. Uzun, yorucu ve özenli çalışmanın sonucunda harcanan emek, editörü bilgiç ve bilge olmaya bir adım daha yaklaştırırken; editörün edindiği amac1, hem bireysel hem de toplumsal çevresini değiştirme gücüne dönüşmektedir. Bu bağlamda editörün üstünlüğü, kendini aşması sonucu lektör olma durumu ortaya çıkmaktadır. Lektör, "yayınevlerinde yayımlanması düşünülen eserleri inceleyerek değerlendiren kimse" (Türk Dil Kurumu, 2017b) olarak incelikli düşünmenin, ayrıntı peşinde olmanın genel ifadesidir. Kuram, nitelik, özellik ve anlamın oluşturduğu derinlik ile davranışın izi lektörlüğe varmaktadır.

Editörün yeni benliği mutlak olarak içinde bulunduğu atmosferin havasına ve iklim şartlarına göre farklılaşabilmektedir. Editör için nefes alınan, heyecan yaşanılan bilgi yüzeyini yayın ortamları sağlamaktadır. Belirli bir amaca göre oluşturulmuş yayın ortamı/kanalı için editör, mekânın/mekaniğin kuvvetidir. Bireysel yetisi, yaratıcı gücü ve aktif kimliği ile editör, görev aldığ1 ortamın/kanalın temsil yeteneğidir. Yayın dünyasında, giderek önemi anlaşılan ve kendine daha çok yer edinen editör, sorumlu olduğu çalışmanın başlığından, içeriğin sunumundan, biçimsel düzenin sağlanmasından, içeriğin biçimini oluşturan her satırda kendini ortaya koymaktadır. Bir bakıma "hiçbir şey bilmemek, ah ne mutlu bir yaşam" (Erasmus, 2010, s. 53) metaforunu neredeyse alt-üst ederek, bilerek yaşamanın acı da olsa en büyük haz olduğu izdüşümünü yansıtmaktadır.

Bilimsel ve mesleki dergilerden bireysel ve tüzel yayınevlerine kadar olan geniş bir yelpazede editörler; güvenilen ve dost kimselerdir. Yaratıcı ve yenilikçi çabalarla, heyecan taşıyan yeni makaleler, kitaplar vb. için kaygıların giderilmesinde yazar(lar)ın yardımcısıdır. Tek boyutlu bilginin, üç boyutlu hâle gelmesinde tüm hazırlık süreçlerini yöneten editöre büyük gereksinim vardır. İyi bir yayın ortamı/kanalı için editör etkin, etkili ve etkendir. Yayın ortamının/kanalının özgürlüğü ve özgünlüğü biraz da bu duruma bağlıdır. Her yayın ortamının/kanalının bağımsız ve bağımlı değişkenleri farklılık gösterse de, önem faktörleri yer değiştirebilir olsa da, sahip olunan tüm enstrümanların armonisini editör tümlemektedir.

Çağcıl ve yeni zamanda editöre olan öznel ve nesnel gereksinim tüm çıplaklığıyla belirmektedir. Bilinmelidir ki "her şeyden önce iyi bir okur olmalıdır editör" (Andaç, 2014a). Editörün saklısında duran; nesnelerin gerçekliği ve bilginin geçerliliği her zaman çıkar yoldur. Bunun, etki yapan ve etken olan yeteneği ise iyi okur olmaya bağlıdır. Yazarların, böylesi bir tutumu her zaman taşıması beklenilemese de, editör için iyi bir okur olmak mutlak nitelik demektir. Editörün yeterlilik ve donanımı her şeyden önce iyi okur olma parıltısı taşımaktadır. Geçmiş tükendikçe ve gelecek çoğaldıkça görülmektedir ki süreklilik kendi bilgi sisteminde sürdürülebilirliği doğurmaktadır. Okumanın artan tutkusu, yeni keşiflerin/arayışların keyfi ve her defasında edilen yeni merak duygusu sonucu editörlük, yeni zamanlarda belli bir akademik eğitim ile kazanılan saygın bir meslek olup çıkacaktır. Okumak, anlamak ve öğrenmek için duyulan istek, profesyonelleşme ve uzmanlaşma getirmekte ve hatta editörlerin ekollerini yaratmasına olanak sunmaktadır. Çıkılan yol, sürülen iz, taşınan misyon ve varılan durak bağlılığın/tutkunun sonucudur. Gereken ilgiyi göstererek, özenli davranarak, dikkatli okumalar 
yaparak, olumlu-olumsuz eleștirileri göze alarak yazara, kitaba, makaleye başvurular editörün başarısını arttırmaktadır. Editörlerin yolunun aydınlanması ve yüzünün ağarması böylesi organik bir sürecin başarısına bağlı bulunmaktadır.

Bilincin, belleğin ve bilginin toplanmasına olduğu kadar oluşturulan toplamın analizlenmesi, incelenmesi ve sentezlenmesi de editör için mutlak temel ilkelerdir. Her alanın kendi sistematiğine ve işleyişine göre farklılık taşımakta olsa da özünde bilgi edinme ve paylaşma sevgisinin bulunduğu rahatlıkla görülmektedir. Özellikle, bilimsel yazın alanında doğru bilginin, doğru yerde ve doğru zamanda kullanılması temel esası oluştururken diğer ifadelerin teferruat olduğu savunulabilir. Bir diğer ifadeyle bilimsel yazın alanında esası etik ve akademik dürüstlük oluşturmakla birlikte bu konuda hem yazarın hem de editörün özenli davranması birincil öncelik olmaktadır. Bir işin elden geldiğince iyi olmasına çabalamanın çok ötesinde, bilgi işinin/uğraşının doğruluktan ayrılmadan, yansız, yanlışsız ve kurallara uygun olarak yapilması oldukça önemlidir.

Editörün belirli bir alandaki uzmanlığ1, yetkinliği ise editoryal sürecin sağlığı açısından bir o kadar önem ve öncelik taşımaktadır. Düzeltmenlik, redaktörlük yapmanın çok ötesinde yazara yazdıklarını sorgulatabilme gücü taşıyan editör, asal işini başarıyla yerine getirmiş sayılacaktır. Dolayısıyla "bir editör iyi bir okur olduğu kadar iyi yazı yazan biri de olmalı, metin kurmayı bilmelidir" (Andaç, 2014b). Editörün uzmanlığı, alan hâkimiyeti ve konu derinliği yayın ortamının/kanalının etki faktörünü yükseltecek, ulusal ve uluslararası prestiji arttırabilecektir. Böylesi bir yetkinlik, özgünlük ve özgürlük editörün olduğu kadar yayın ortamının/kanalının ilişkinliğini tamamlayacak ve işlevselliğini üstlere taşıyacaktır. Yinelemek gerekir ki editörün entelektüel birikimi kendisinin olduğu kadar sorumlu olduğu yayın ortamı/kanalı mecrasının, nasıl bir macera içinde olacağını da belirlemektedir. Şüphesiz, bilgi/yazar/eser faktörlerinin bütünlüğünün sağlanması ve yönetilmesinde editöre olan gereksinim büyüktür. Üstelik editöre gerekli olanak ve özgürlük sunulursa, yayın ortamının/kanalının görevdaşlığıyla aktif gücün artarak toplamdan daha fazla olmasına katkı sunacaktır.

Günümüzde, editörlük belirli bir kültür düzeyi ve yeterliliği gerektirmektedir. Bilgiye ait olan her ürünü/üretimi estetik bir değer olarak kabul etmekle birlikte esenlik kaynağı olarak da görmektedir. Dünden beslenen, bugüne not düşen ve geleceği öngören editör, kimsenin değirmenine su taşımamaktadır. Yeniliğin bilgi ile geleceğine inanmakta, entelektüel uğraşını sürdürmekte ve bilginin kalıcılığı/sürekliliği için çalışmaktadır. Editör; günün istemlerinin uzağında, kol kola ilişkilere girmeden, bir üst-bakış olarak bilinç, bilgi ve bilim için hep var olacaktır.

\section{Kaynakça}

Andaç, F. (2014a). Editörlük ne değildir? (I). Erişim adresi: http://www.edebiyathaber.net/editorluk-nedegildir-i-feridun-andac/

Andaç, F. (2014b). Editörlïk ne değildir? (II). Erişim adresi: http://www.edebiyathaber.net/editorlukne-degildir-ii-feridun-ancac/

Erasmus, D. (2010). Deliliğe övgü. (Ç. Dürüşken, Çev.). (2. bs.). İstanbul: Kabalcı Yayınevi.

Türk Dil Kurumu. (2017a). Güncel Tiürkçe sözliuk: editör. Erişim adresi: http://tdk.gov.tr/index.php?option=com_gts\&arama=gts\&guid=TDK.GTS.58771bd355f270.12700023

Türk Dil Kurumu. (2017b). Güncel Türkçe sözlük: lektör. Erişim adresi: http://www.tdk.gov.tr/index.php?option=com_gts\&arama=gts\&guid=TDK.GTS.5875dc929167a 2.13390149 